\title{
EFFECTS OF SHORT-TERM NITROGEN AND PHOSPHORUS ADDITION ON ROOT BIOMASS AND MORPHOLOGICAL CHARACTERISTICS OF LIGUSTRUM LUCIDUM AIT IN NEW RECLAMATION COASTAL FIELD
}

\author{
WANG, Z. ${ }^{1,2}-$ LIU, X. ${ }^{2}-$ ZHANG, L. ${ }^{1,2}-$ JIANG, H. ${ }^{4}-$ DU, H. ${ }^{5}-$ YANG, D. ${ }^{6,7}-$ WU, H. ${ }^{3}-$ \\ LIANG, J. ${ }^{3 * *}-\mathrm{CAI}, \mathrm{Y}^{1,2^{*}}$ \\ ${ }^{1}$ Shanghai Key Lab for Urban Ecological Processes and Eco-Restoration \\ Shanghai 200241, China \\ ${ }^{2}$ School of Ecological and Environmental Sciences, East China Normal University \\ Shanghai 200241, China \\ ${ }^{3}$ Shanghai Academy of Landscape Architecture Science and Planning, Shanghai 200232, China \\ ${ }^{4}$ Ecological Engineering College, Guizhou University of Engineering Science \\ Bijie 551700, Guizhou, China \\ ${ }^{5}$ Shanghai Academy of Social sciences, Shanghai 200020, China \\ ${ }^{6}$ School of Geographic Sciences, East China Normal University, Shanghai 200241, China \\ ${ }^{7}$ Henan Key Laboratory of Integrative Air Pollution Prevention and Ecological Security, \\ College of Environment and Planning, Henan University, Kaifeng 475004, China \\ *Corresponding authors \\ e-mail:ylcai@geo.ecnu.edu.cn \\ (Received $9^{\text {th }}$ Jan 2019; accepted $6^{\text {th }}$ Mar 2019)
}

\begin{abstract}
Root system plays an important role in plant's nutrient acquisition and ecosystem carbon cycle. Nitrogen $(\mathrm{N})$ and phosphorus $(\mathrm{P})$ work significantly in promoting root system growth. To reveal the influence of $\mathrm{N}$ and $\mathrm{P}$ application on landscaping plants' root morphology characteristics, Ingrowth soil core fertilization method was applied in the coastal reclaimed soil $\left(196.25 \mathrm{~cm}^{3}\right)$ where Ligustrum lucidum ait grew from June to August in 2018. We set 11 processing gradients, including 0, 1, 3, 5, 7, 9, 11, 13, 15, 17 , $20 \mathrm{~g}$, and explored the influence of different $\mathrm{N}$ and $\mathrm{P}$ addition types on Ligustrum lucidum ait root morphology, biomass and other indicators. The results showed that compared with the control group, $3 \mathrm{~g}$ $\mathrm{N}$ application increased length of root by $62.39 \%$, surface area by $120.87 \%$, volume by $169.97 \%$, biomass by $102.75 \%$, root length density by $59.19 \%$ and root surface area density by $106.99 \% .3 \mathrm{~g} \mathrm{P}$ application increased those indexes by $77.37 \%, 111.15 \%, 147.50 \%, 98.05 \%, 73.87 \%$, and $97.88 \%$. The study indicated that compared with the control group, the application of $3 \mathrm{~g} \mathrm{~N}$ and $\mathrm{P}$ into $196.25 \mathrm{~cm}^{3}$ soil made significant differences on total length, diameter, surface area, volume, biomass, root length density, and root surface area density $(P<0.05)$.
\end{abstract}

Keywords: root system, plant's nutrient acquisition, biomass, root morphology, Ligustrum lucidum ait

\section{Introduction}

Most of the new coastal reclamation areas are the new land which forms through the sediment's being dredging from the seabed into the coastal tidal flat. After many years of natural desalination, salt washing and land abandonment for soil salinity reducing, they have gradually got suitable for the growth of green vegetation. However, this type of soil 
is extremely deficient in nutrients, such as nitrogen and phosphorus, which is the key factor that restricts the growth of plants. The lack of nitrogen and phosphorus in soil will slow the growth of vegetation, which will affect the artificial afforestation and ecological restoration in the reclamation area. The problem of artificial afforestation and ecological restoration in the new coastal reclamation area is urgent to be solved.

The survival of artificial afforestation is determined by plant roots. Root system is the interface between plants and soil, and is an important organ that absorbs nutrients and water. Nutrient content in soil directly affects plant growth. The addition of nitrogen and phosphorus to soil can change the influence of soil environment, and then affect the characteristics of plant root system. Roots often adapt to the environmental changes by adjusting the characteristics of root system, such as morphology, surface area, volume and biomass, showing high plasticity (Pregitzer et al., 1993; Eissenstat and Yanai, 1997; Eissenstat et al., 2000; Robinson, 2010; Wurzburger and Wright, 2016). Studies have shown that, under the condition of poor soil nutrients, the application of nutrient elements can help the root system grow rapidly enough to adapt to the changes in the environment (Schiefelbein and Benfey, 1991; Pregitzer et al., 1993; Bates and Lynch, 1996; Pregitzer et al., 1997, 2002; Wells et al., 2010; Robinson, 2010). For example, increased availability of soil nitrogen can lead to an increased fine root length, higher biomass and coarser diameters (Lynch, 1995; Messier, 2002; Pregitzer et al., 2002). It has also been found that $\mathrm{N}$ application increases root surface area and total length (King et al., 1997). It can also significantly affect the diameter, root length and specific root length of lower root order (Fitter and Stickland, 1991). Root plasticity has the same response to phosphorus (Fitter et al., 2010). For example, with the increase of soil phosphorus availability, Larix gmelinii increased root length to enhance the absorption of $\mathrm{P}$, leading to the significant differences in root volume and lateral root tillers of Pinus massoniana in different species (Lynch, 1995).

However, most previous studies focused on the good soil environment and indoor experiments. The researches on phosphorus content in the wild arid field are very few. Then, the soil's nitrogen and phosphorus adding referred to be the surface spraying method, which was easily affected by weather (rain, snow), thus causing errors in the experiment results. Meanwhile, the way of adding nitrogen and phosphorus to soil was to apply fertilizer to the existing roots. The sampled roots included both old roots and new roots which grew right after the nutrient adding, so it's impossible to determine its specific influence on the characteristics of old roots or new roots. Ingrowth soil core avoids the above problems and can help master the growth characteristics of new root under different treatment conditions. And it can also contribute to clarifying the relationship between new root characteristics and soil nutrients (Peterjohn et al., 1999; Mcgrath et al., 2001).

Therefore, this study chose Ligustrum lucidum ait which grew on Shanghai coastal reclaimed soil with poor nitrogen and phosphorus content as the research object, applied ingrowth soil core to carry out short-term experiment of nitrogen and phosphorus adding to investigate the response of Ligustrum lucidum ait root morphology, biomass and other characteristics to soil's short-term nitrogen and phosphorus addition, so as to provide basic reference materials for the study on the relationship between root morphology and soil resource effectiveness as well as the construction and ecological restoration of artificial forests. 


\section{Materials and methods}

\section{Study area}

The field site ( $\left.30^{\circ} 52^{\prime} 54^{\prime \prime} \mathrm{N}, 121^{\circ} 54^{\prime} 24^{\prime \prime E}\right)$ was located in Lingang new Urban area in Shanghai (Fig. 1). It was damp, windy, warm, humid with abundant rainfall as well as with abundant sunshine in the region with four distinct seasons. And the annual average temperature in 2018 was $15^{\circ} \mathrm{C}$ to $15.8^{\circ} \mathrm{C}$, with the lowest temperature $\left(3.3^{\circ} \mathrm{C}\right)$ in January, the highest temperature in August $\left(38^{\circ} \mathrm{C}\right)$. The annual total sunshine was $2000-2200 \mathrm{~h}$, the annual precipitation was $900-1050 \mathrm{~mm}$ and the monthly average evaporation is 91.9 $\mathrm{mm}$, which was a typical subtropical maritime climate. Soil was that of saline and alkaline sandy soil. Soil with a $\mathrm{pH}$ value greater than 8.5 took up $97.5 \%$, and the organic matter content was less than $20 \mathrm{~g} / \mathrm{kg}$. The groundwater level was between 0.5 and $2.5 \mathrm{~m}$. In order to solve the problem of barren soil vegetation, different vegetation planting experiments were carried out. Vegetation planting began in February 2010 and was completed in April 2010. The test site was $1200 \mathrm{~m}$ long, $20 \mathrm{~m}$ wide and $24000 \mathrm{~m}^{2}$ for total area. All the plants in the site were native species. Representative plant Ligustrum lucidum ait was selected as the experimental sample.
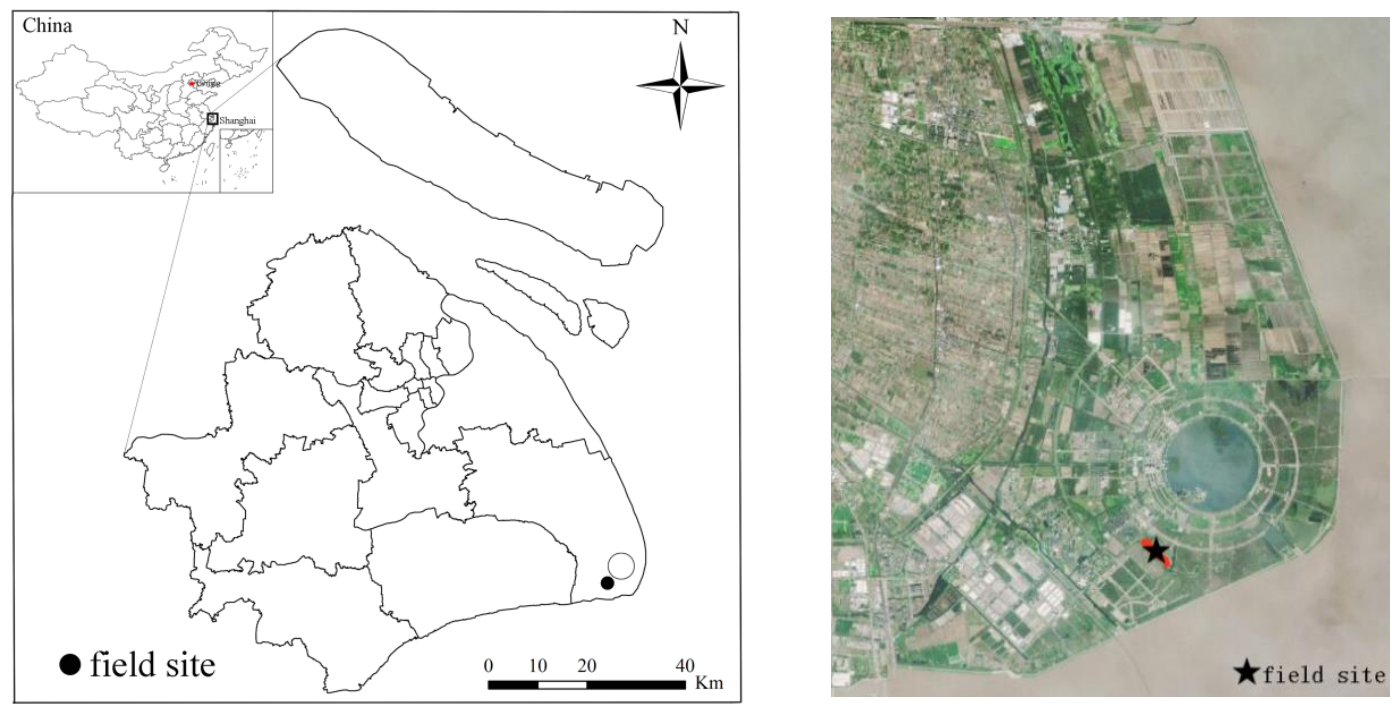

Figure 1. Map of the study area

\section{Plot design}

In the privet plantation ( 8 years old), a fixed standard plots of $20 \times 30 \mathrm{~m}$ were set, and the privet with the same chest diameter, crown width and tree height were selected as samples in the sample plot (Table 1). The field within $1 \mathrm{~m}$ from the tree trunk was fertilized. A total of three groups were designed. I for nitrogen treatment, ten fertilizing gradients were set as: 1, 3, 5, 7, 9, 11, 13, 15, 17, $20 \mathrm{~g}$; II for phosphorus processing, the gradients were set the same as those of nitrogen; III no treatment was done as a control.

Plant root sampler $(1=10 \mathrm{~cm}, \varphi=5 \mathrm{~cm}, \mathrm{~h}=10 \mathrm{~cm})$ was used. Most root system evenly distributed in surface area (Wang, 2004; Jiang, 2016), and the sampling depth was $10 \mathrm{~cm}$. Then with the trunk as the center, $1 \mathrm{~m}$ from the center of trunk as the radius for sampling, 9 soil column samples were taken at the same distance around each tree, and 3 privet samples were taken as a treatment (Fig. 2). There was a total of 63 samples of Ligustrum 
lucidum ait, and a total of 567 sample points were set. All roots were removed from soil cores with a sieve with a diameter of $3 \mathrm{~mm}$. The soil was kept without roots, and then $\mathrm{N}$, $\mathrm{P}$ was added to the soil. 270 soil cores of 30 privet samples were dealt with $\mathrm{N}$ of the 10 gradients, while another 270 soil cores of 30 privet samples were dealt with $\mathrm{P}$ of the 10 gradients, and 27 sampling points of three privet samples were not done with any fertilizer processing thus as a control.

Table 1. Tree and Soil characteristics properties

\begin{tabular}{c|c|c|c}
\hline \multicolumn{2}{c|}{ Tree characteristics } & \multicolumn{2}{c}{ Soil characteristics } \\
\hline Tree height $(\mathrm{m})$ & $4.37 \pm 0.31$ & $\mathrm{pH}$ & $8.79 \pm 0.09$ \\
DBH $(\mathrm{cm})$ & $10.01 \pm 0.27$ & $\mathrm{EC}(\mathrm{ms} / \mathrm{cm})$ & $0.42 \pm 0.06$ \\
Crown width (m) & $2.31 \pm 0.25$ & Organic matter $(\mathrm{g} / \mathrm{kg})$ & $3.60 \pm 0.63$ \\
Plant distance (m) & $3 \times 3$ & Total salt content $(\mathrm{g} / \mathrm{kg})$ & $0.78 \pm 0.03$ \\
Planting age (years) & 8 & Bulk density $\left(\mathrm{g} / \mathrm{cm}^{3}\right)$ & $1.37 \pm 0.02$ \\
& & Soil Moisture $(\%)$ & $29.23 \pm 2.92$ \\
& & Total N $\left(\mathrm{g} \cdot \mathrm{kg}^{-1}\right)$ & $0.82 \pm 0.04$ \\
& & Total P $\left(\mathrm{g} \cdot \mathrm{kg}^{-1}\right)$ & $0.27 \pm 0.02$ \\
& & Total K $\left(\mathrm{g} \cdot \mathrm{kg}^{-1}\right)$ & $11.85 \pm 0.73$ \\
& & Texture & Sand loam \\
\hline
\end{tabular}

Data are provided in the form of mean \pm standard deviation (SD). $D B H$ diameter at breast height or basal
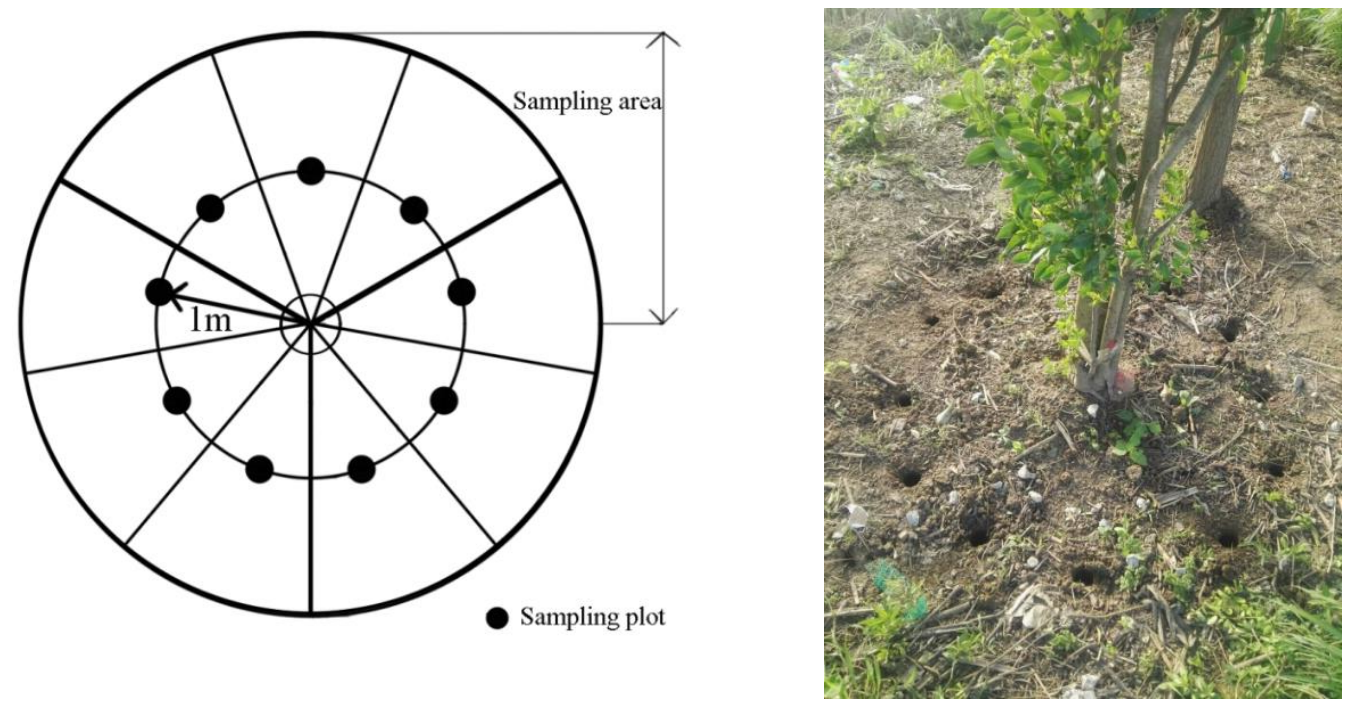

Figure 2. Sample points for soil $N$ and $P$ addition

Urea $\left(\mathrm{CON}_{2} \mathrm{H}_{4}, 43 \%\right.$ nitrogen content) was chosen as $\mathrm{N}$ fertilizer and calcium superphosphate $\left(\mathrm{P}_{2} \mathrm{O}_{5}, 13 \%\right.$ phosphorus content) as $\mathrm{P}$ fertilizer. Then the treated soil was put into nylon mesh bags with a pore size of $2 \mathrm{~mm}(\mathrm{l}=10 \mathrm{~cm}, \mathrm{w}=6 \mathrm{~cm})$, then the nylon mesh bags were placed in the cavities made through the core drilling. Then the soil inside the cores was gently patted, making its bulk density to a certain extent consistent with the surrounding soil bulk density. Then PVC tubes were put in the core positions $(\varphi=5 \mathrm{~cm}$, $\mathrm{h}=1 \mathrm{~cm}$ ). The PVC pipes were covered with thin soil, in case that soil erosion caused by rainfall should affect the experiment results. The soil cores were set from June $16^{\text {th }}, 2018$ to June $18^{\text {th }}, 2018$ when it's the peak growth season for privet root system as well as the 
most demanding season of privet for nitrogen and phosphorus fertilizer to blossom. During the study period in 2018 , the average temperature was $18 \sim 28^{\circ} \mathrm{C}$. The average precipitation was $134 \mathrm{~mm}$. The average soil moisture content was $19.09 \%$, and the average soil temperature was $21.34^{\circ} \mathrm{C}$. The average temperature in July was $21 \sim 30^{\circ} \mathrm{C}$, the average precipitation was $156 \mathrm{~mm}$, the average moisture content of soil was 27.58, and the average temperature of soil was $28.41^{\circ} \mathrm{C}$. In August, the average temperature was 20 $\sim 30^{\circ} \mathrm{C}$, the average precipitation was $140 \mathrm{~mm}$, the average moisture content of the soil was 23.79 and the average temperature of the soil was $26.51^{\circ} \mathrm{C}$.

\section{Root sampling}

The fine roots of Ligustrum lucidum ait grew slowly after August, so the soil cores was removed again (Wang, 2004; Jiang, 2016) after 60 days of root removal (in midAugust). The roots between nylon mesh and soil were cut off with a sharp soil knife. The soil cores were cut with a soil knife at the bottom and the excavated cores were taken out. Then, they were put into plastic bags and brought back to the laboratory in time.

\section{Root determination}

After the soil core being fully rinsed in water, the roots in nylon bags were sifted out with a soil sieve with a $2 \mathrm{~mm}$ diameter and the root surface were dried with absorbent paper. The prepared root samples were placed in a transparent scanner tray for the roots' full stretching. The root samples were scanned with a digital scanner Epson scanner. The root scan \& analysis system of Win-RHIZO 2005C (Regent Instruments Inc., Quebec, Canada) was used to scan the root image and the length, diameter, surface area and other data of the root system were obtained then. Afterwards, root samples were placed in $80^{\circ} \mathrm{C}$ oven for drying for $48 \mathrm{~h}$ to a constant weight, and then the dry weight was weighed (accuracy: $0.0001 \mathrm{~g}$ ). According to the root length and dry weight of each sample point, we calculated the biomass and specific root length, and then calculated root length density, specific surface area and surface area density according to the root length, surface area and the volume of soil cores. Finally, we calculated the average value of the samples in 27 soil cores in each treated soil layer and converted the average values into root biomass, root length density, specific root length, specific surface area, and root surface area density per unit volume. Root biomass, root length density, specific root length, specific surface area, and root surface area density were calculated as follows:

$$
\begin{gathered}
\text { Root biomass }\left(\mathrm{g} / \mathrm{m}^{2}\right)=\mathrm{g} \times \mathrm{A} \\
\text { Root length density }\left(\mathrm{m} / \mathrm{m}^{3}\right)=\mathrm{L} / \mathrm{V} \\
\text { Specific root length }(\mathrm{m} / \mathrm{g})=\mathrm{m} / \mathrm{g} \\
\text { Specific surface area }\left(\mathrm{cm}^{2} / \mathrm{g}\right)=\mathrm{a} / \mathrm{g} \\
\text { Root surface area density }\left(\mathrm{m}^{2} / \mathrm{m}^{3}\right)=\mathrm{a} / \mathrm{V}
\end{gathered}
$$

where, a is Root surface area; A is the area of soil; $\mathrm{g}$ is fine root dry weight; L is total length of fine root; $\mathrm{m}$ is the length of dry fine root in each Sample point; $\mathrm{V}$ is the volume of soil. 


\section{Statistical analysis}

The average value of each processed sample was calculated and was ready for statistical analysis. Univariate anova and LSD multiple comparisons $(\alpha=0.05)$ were used to test the significant differences in the effects of different nitrogen and phosphorus addition treatments on the total length, average diameter, surface area, volume, biomass, specific root length, root length density, specific surface area, and root surface area density of the great privet root system. All statistical analyses were performed with SPSS 20.0 (IBM SPSS, Chicago, USA) software. Excel 2010 software was used to draw pictures.

\section{Results}

\section{Effects of $N$ and $P$ addition on root morphology}

As is seen in Fig. 3a, the total length of the root-system of Ligustrum lucidum ait appeared to increase first and decrease later under different $\mathrm{N}$ treatments. When 1 and $3 \mathrm{~g}$ were added, compared with the control group, the total length of root significantly increased by $57.62 \%$ and $62.39 \%(P<0.05)$, when $5-11$ g nitrogen were respectively applied, the total length of root system decreased gradually. No root growth was observed when $13 \mathrm{~g} \mathrm{~N}$ was applied. Under different $\mathrm{P}$ treatments, when 1 and $3 \mathrm{~g}$ were added, the root total length increased by $9.50 \%$ and $77.37 \%(P<0.05)$. With 5-20 g applied, the total length of the root system gradually decreased, but no non-root-growth was found (Fig. $3 a)$.

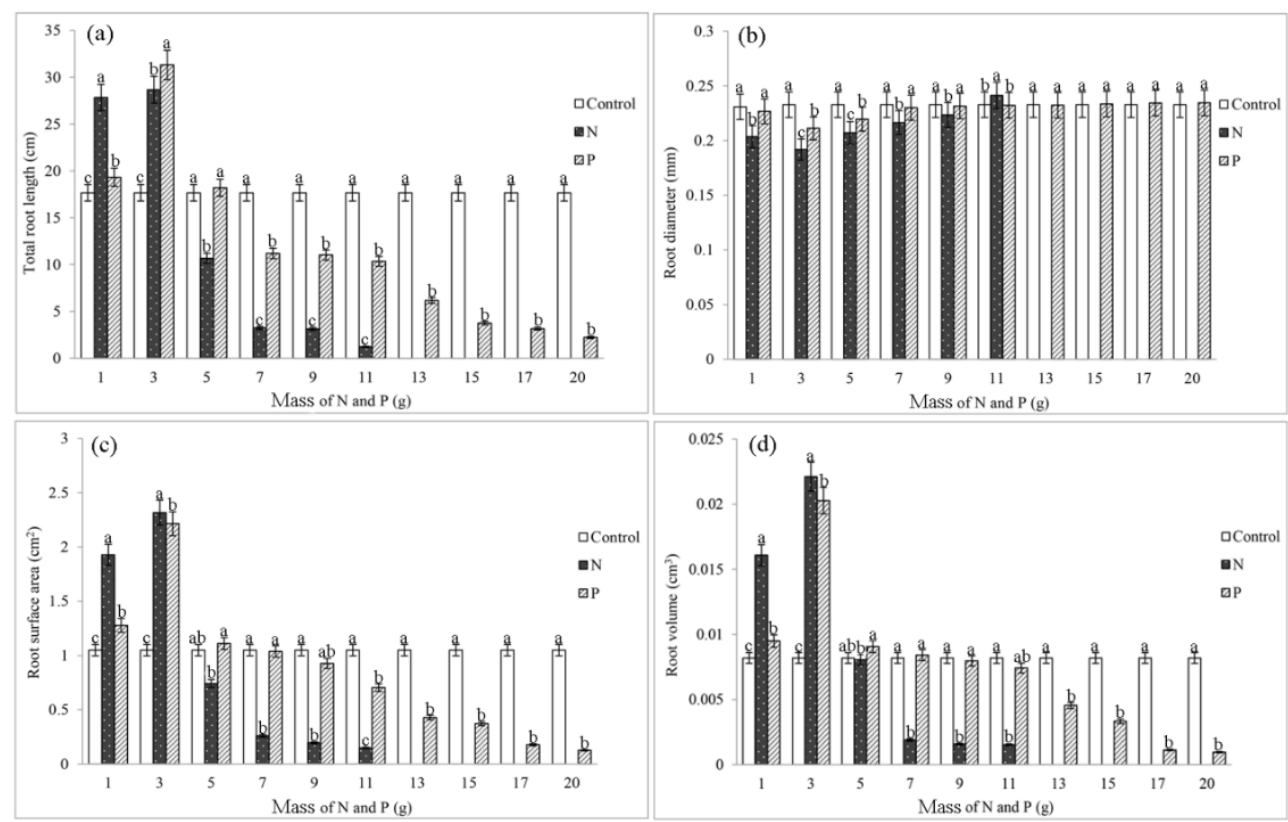

Figure 3. Effects of fertilization on the morphology of the root system of Ligustrum lucidum ait.(a) total root length, (b) root diameter, (c) root surface area, (d) root volume

The average diameter of root showed a tendency of thinning first and thickening then under different nitrogen and phosphorus treatments (Fig. 3b). Compared with the control group, the average diameter of the privet roots was thinned and significant difference was 
found when 1 and $3 \mathrm{~g} \mathrm{~N}$ were applied $(P<0.05)$. When $3 \mathrm{~g} \mathrm{~N}$ was applied, the average diameter of root system reduced to the minimum, $0.19 \mathrm{~mm}$. The average diameter of root system gradually increased when 5-11 g nitrogen were applied, and the maximum diameter $0.24 \mathrm{~mm}$ appeared at $11 \mathrm{~g}$. When 1-20 g P were applied, the average diameter of roots showed a trend of thickening after thinning. When $3 \mathrm{~g} \mathrm{P}$ was applied, the average diameter of the root system reduced to the minimum and the significant difference was achieved $(P<0.05)$. When $20 \mathrm{~g} \mathrm{P}$ was applied, the maximum diameter was $0.23 \mathrm{~mm}$.

When 1, $3 \mathrm{~g} \mathrm{~N}$ and $\mathrm{P}$ were applied, the average surface area and volume of root system gradually increased and the significant difference occurred, compared with the control group $(P<0.05)$ (Fig. 3c,d). The root surface area increased by $45.61 \%$ and $120.87 \%$, and root volume increased by $96.34 \%$ and $169.97 \%$ when 1 and 3 g nitrogen were applied. With 5-11 g N, root surface area and volume gradually decreased. When 1 and $3 \mathrm{~g} P$ were applied, the root surface area increased by $21.79 \%, 111.15 \%$, and the volume $15.96 \%$, $147.50 \%$. And the difference was significant $(P<0.05)$. When $11-20 \mathrm{~g} \mathrm{P}$ were applied, compared with the control, no significant difference was found about the root diameter $(P>0.05)($ Fig. 3b).

\section{Effects of $N$ and $P$ addition on root biomass, root length density and specific root length}

As is seen in Fig. 4a, with the increase of nitrogen and phosphate application, root biomass showed a trend of increasing first and decreasing then. Compared with the control group, the biomass and root length density of privet root increased and significant differences were found when $3 \mathrm{~g} \mathrm{~N}$ and $\mathrm{P}$ were applied $(P<0.05)$.

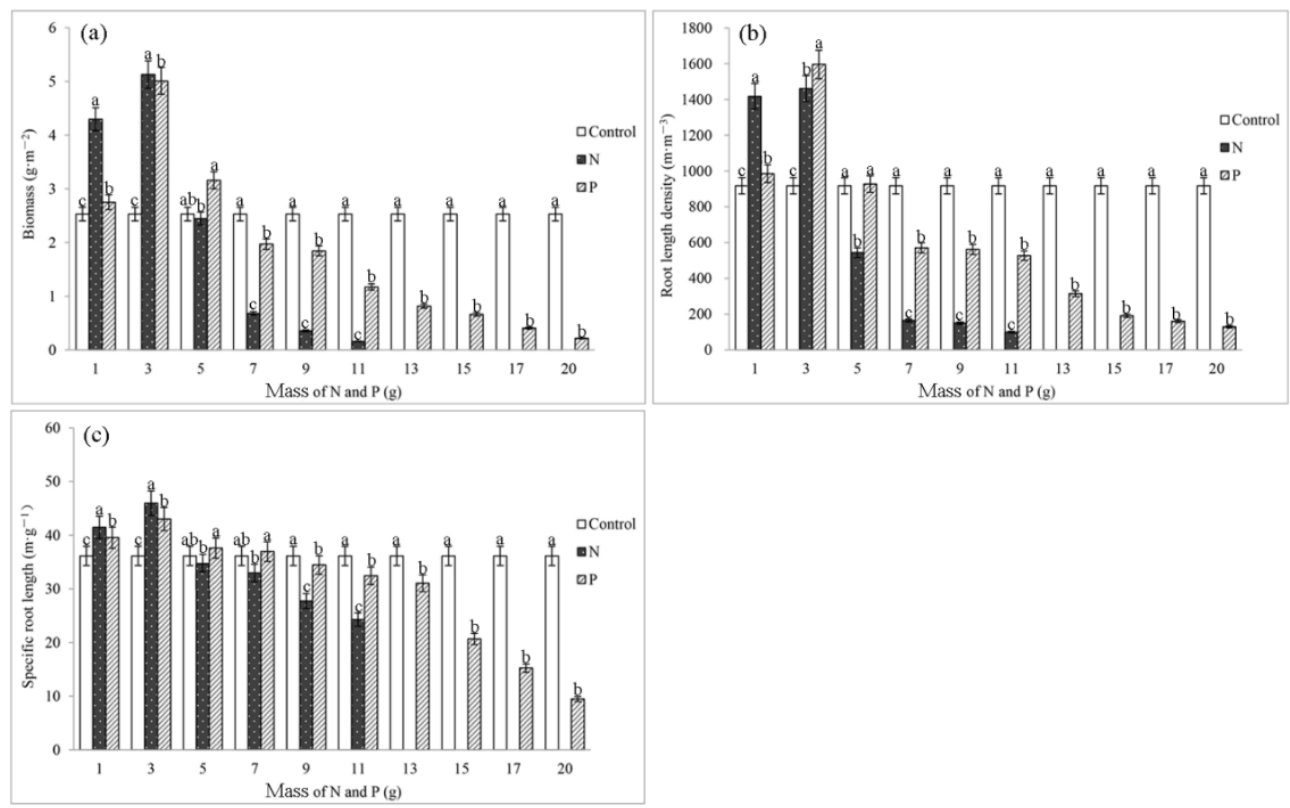

Figure 4. Effects of fertilization on root biomass (a), root length density( $b$ ), and specific root length(c) of Ligustrum lucidum ait

The application of 1 and $3 \mathrm{~g} \mathrm{~N}$ increased the biomass by $69.85 \%$ and $102.75 \%$, respectively $4.30 \mathrm{~g} \cdot \mathrm{m}^{-2}$ and $5.13 \mathrm{~g} \cdot \mathrm{m}^{-2}$, and it also increased the root length density by $54.51 \%$ and $59.19 \%$, respectively $1417.99 \mathrm{~m} \cdot \mathrm{m}^{-3}$ and $1460.90 \mathrm{~m} \cdot \mathrm{m}^{-3}$. The application of $3 \mathrm{~g} \mathrm{P}$ increased the biomass by $98.05 \%$ and the root length density by $73.87 \%$, respectively $5.01 \mathrm{~g} \cdot \mathrm{m}^{-3}$ and $1595.62 \mathrm{~g} \cdot \mathrm{m}^{-2}$ (Fig. $\left.4 a, b\right)$. 
With the increase of $\mathrm{N}$ application, specific root length increased first and decreased then. When 1 and $3 \mathrm{~g} \mathrm{~N}$ and $\mathrm{P}$ were applied, the specific root length significantly increased compared with the control $(P<0.05)$ (Fig. $4 c)$. The maximum specific root length reached $45.96 \mathrm{~m} \cdot \mathrm{g}^{-1}$ and $43.01 \mathrm{~m} \cdot \mathrm{g}^{-1}$ when nitrogen and phosphorus were applied to the roots respectively. The effect of nitrogen on specific root length was more significant compared with phosphate. When 5-11 g nitrogen were applied, the specific root length gradually reduced. The root stopped growing at $13 \mathrm{~g}$. When 5-20 g phosphate fertilizer were applied, the specific root length gradually reduced.

\section{Effects of $N$ and $P$ on specific surface area and surface area density}

As is seen in Fig. 5a, with the increase of $\mathrm{N}$ and $\mathrm{P}$ application, the specific surface area of root showed a trend of increasing first and decreasing then. Compared with the control group, the root specific surface area reached the maximum and significant difference was found $(P<0.05)$ when $7 \mathrm{~g} \mathrm{~N}$ and $\mathrm{P}$ were applied $\left(350.20 \mathrm{~cm}^{2} \cdot \mathrm{g}^{-1}\right.$ and $\left.279.02 \mathrm{~cm}^{2} \cdot \mathrm{g}^{-1}\right)$. With the increase of $\mathrm{N}$ and $\mathrm{P}$ application, the surface area density increased first and decreased then (Fig. 5b). Compared with the control group, the root surface area density had a significant difference $(P<0.05)$ when 1 and $3 \mathrm{~g} \mathrm{~N}$ and $\mathrm{P}$ were applied. The root surface area density was also the largest, increasing by $106.99 \%$ and $97.88 \%$, respectively, which were $1.18 \mathrm{~m}^{2} \cdot \mathrm{m}^{-3}$ and $1.13 \mathrm{~m}^{2} \cdot \mathrm{m}^{-3}$ when $3 \mathrm{~g} \mathrm{~N}$ and $3 \mathrm{~g} \mathrm{P}$ were added (Fig. 5b).

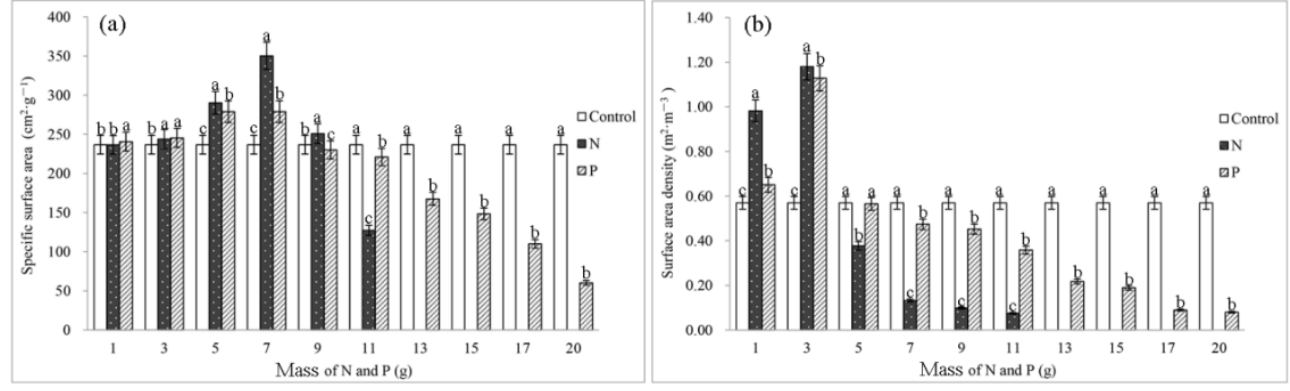

Figure 5. Effects of fertilization on specific surface area (a) and surface area density $(b)$ of the root system of Ligustrum lucidum ait

\section{Discussion}

\section{Effects of $N$ and $P$ addition on root morphology}

Studies have shown that plant roots are highly plastic and can respond to the availability of different soil $\mathrm{N}$ and $\mathrm{P}$ contents. That is to say, when nutrients are limited, the ability to obtain nutrients can be improved by increasing the total length, surface area and volume of roots (Cuevas et al., 1991; Schmid and Kazda, 2002; Yang et al., 2003).

Increasing root length is an effective strategy for plants' nutrient and water obtaining. Under the treatments of $3 \mathrm{~g} \mathrm{~N}$ and $3 \mathrm{~g} \mathrm{P}$, the total length of root system increased by $62.39 \%$ and $77.37 \%$, Wang et al. (2005) got this result too. Different nitrogen and phosphorus treatments had different effects on the total length of the root system of privet (Fig. 3a,b). Among those, $1 \mathrm{~g}, 3 \mathrm{~g} \mathrm{~N}$ and $\mathrm{P}$ significantly increased the total length of root system. 5-11 g N applications significantly decreased the total length of root system. No root growth was observed when 13-20 g N were applied. The total length of root system 
significantly decreased when 5-20 g P were applied and no root growth was found. The reason was that the application of $1 \mathrm{~g}, 3 \mathrm{~g} \mathrm{~N}$ and $\mathrm{P}$ can change the ways of root system to obtain nutrient resources, promote the growth of the root system, and reflect the effects of $\mathrm{N}$ and $\mathrm{P}$ on the promotion (positive feedback) of the root system. Secondly, the lignification degree of the newly formed root system was low, which was easily affected by the soil environment and was very sensitive to the changes of soil resources. To obtain more nutrients, the root system grew rapidly. The applications of 5-20 g N and P inhibited the root growth to some extent, especially the death of plant roots was found after $13 \mathrm{~g}$ addition of $\mathrm{N}$.

Root diameter is an important parameter reflecting root structure and function (Robinson, 2010). Under different nitrogen and phosphorus treatments, the average diameter of root showed the phenomenon of first thinning and then thickening (Fig. 3b). $\mathrm{N}$ application of $1 \mathrm{~g}, 3 \mathrm{~g}$ and $5 \mathrm{~g}$ had a significant impact on the average diameter of root system, under which the average diameter became thinner. The average diameter under $\mathrm{P}$ application of 5-20 g gradually increased. The reason why the diameter first decreased and then increased under different fertilization treatments was that under the condition of low addition of $\mathrm{N}$ and $\mathrm{P}$, the extension of root cells made the root diameter decrease for the root system to obtain more nutrient resources. With the high addition of $\mathrm{N}$ and $\mathrm{P}, \mathrm{N}$ relatively inhibited the growth of the root system. To survive, the root system changed its survival strategies, appearing to be the increase of the root diameter and the prolonging of the root life to obtain nutrients and maintain its survival. For example, Wells et al. (2002) proved the relationship between root life and diameter of Amygdalus persica $l$. And it testified to a significant positive correlation between root life and diameter (Wells et al., 2002). Kern (2004)'s research showed that fertilization could significantly increase the root diameter of a poplar and shorten the root turnover time (Kern et al., 2004). According to the characteristics of root plasticity and the "cost-benefit" theory, the growth strategy of the root system always tends to choose the method with the minimum cost and the maximum benefit for survival (Eissenstat and Yanai, 1997; Bardgett et al., 2014).

Different $\mathrm{N}$ and $\mathrm{P}$ treatments can significantly affect root surface area and volume (Fig. 3c,d). Compared with the control group, application of $1 \mathrm{~g}, 3 \mathrm{~g} \mathrm{~N}$ and $\mathrm{P}$ increased root surface area by $45.61 \%, 120.87 \%$, root volume by $96.34 \%$ and $169.97 \%$. The increase of root surface area and volume is a way for the root system to have greater absorption surface area and maximally obtain soil nutrient resources.

\section{Effects of $N$ and $P$ addition on root biomass, root length density, specific root length and surface area density}

Addition of $\mathrm{N}$ and $\mathrm{P}$ significantly affected root biomass and root length density (Fig. 4a,b). At present, the effects of increased soil nitrogen availability on root biomass and production appear to be reduction and increase (Cotrufo and Gorissen, 1997; Kou et al., 2015). For example, the application of $\mathrm{N}$ can increase the fine root biomass of Populus deltoides by $21 \%$ (Kern et al., 2004) and the fine root biomass of Picea abies by $92 \%$ (Majdi, 2001). For example, the application of $\mathrm{N}$ can reduce the fine root biomass of Larix kaempferi by $15 \%$ and that of Pseudotsuga menziesii by $40 \%$ (Son and Wang, 2010). The response of root biomass to $\mathrm{N}$ addition may be related to the climate and soil nutrient conditions in the study area. And the effect of $\mathrm{N}$ addition on root biomass is also related to the genetic characteristics, phenological characteristics, $\mathrm{N}$ addition amount and treatment time of different roots. 
In this study, compared with the control group, the biomass of root significantly increased after 1 and $3 \mathrm{~g} \mathrm{~N}$ application (69.85\% and 102.75\%, respectively) (Fig. 4a). Root biomass significantly decreased after 5-11 g N applications $(P<0.05)$. When $13 \mathrm{~g}$ $\mathrm{N}$ application was applied, no root growth was observed, and high nitrogen directly caused little root growth, reflecting the negative feedback effect of $\mathrm{N}$ on root. The increase of root biomass may be attributed to the increase in the effectiveness of soil $\mathrm{N}$ following the fertilization, which met the demand for $\mathrm{N}$ of the root system. Plant roots adopted the strategy of "rapid investment - income" to increase the carbon distribution to the root system and promote the growth of the root system. High nitrogen inhibits the growth or non-growth of the root system, leading to the reduction of root biomass. With respect to phosphorus addition, the biomass of root significantly increased after the $3 \mathrm{~g}$ phosphate fertilizer application (an increase of $98.05 \%$ ). The reason may be that the phosphorus elements were involved in the composition of nucleic acids, nucleotides, and phospholipids, which was also the main component of cytoplasm and nuclei, so under a reasonable phosphorus add, the elongation of root cells can be increased. The total root length and root length density increased, leading to the increase of biomass. Under the treatment of high phosphorus, the root cell elongation decreased, root length decreased, and the biomass showed a trend of gradual decreasing. Root biomass gradually reduced when 5-20 g phosphate fertilizers were applied.

Specific root length refers to the total root length of unit mass root system, and it is an important indicator of root morphology and physiological function (Eissenstat, 1992; Pregitzer et al., 2002). Studies have shown that the value of specific root length is associated with the effectiveness of soil resources (Burton et al., 2000; Gordon and Jackson, 2000). It is generally believed that a root with a larger length has relatively higher nutrient and water absorption efficiency, and the value of specific root length can indicate the physiological activity of the root (Pregitzer et al., 2002).

The effects on specific root length are manifested in: under low N/P addition, compared with the control, the specific root length significantly increased $(P<0.05)$, and the high addition of N/P (5-20 g) significantly inhibited the increase of root length (Fig. $4 c$ ). The main reason was that the newly formed long roots had low lignification degree and high plasticity, and were easily affected by the soil environment, leading to the root system's length adjustment to satisfy its absorption of nutrients from soil (Guo et al., 2004). Different N and P addition's influence on root length density and surface area density was consistent with that of root biomass (Fig. 4b,5b). Among those, under the application of $5 \mathrm{~g}$ nitrogen and phosphorus, the root length density under phosphorus treatment was $9.22 \%$ higher than that under nitrogen treatment. The reason may be that under reasonable fertilization, phosphate fertilizer can increase the number of root tillers and stem tillers, leading to the increase of underground biomass and root length density.

In general, in the case of $1 \mathrm{~g}, 3 \mathrm{~g} \mathrm{~N}$ and $\mathrm{P}, \mathrm{N}$ had a significant effect on total length, surface area, volume, biomass, and root length density of the root system, whose reason may be related to the mobility of $\mathrm{N}$ and $\mathrm{P}$ elements in soil. Phosphate roots in soil are usually affected by the obligate adsorption of iron oxide and aluminum oxide in soil. In the soil, $\mathrm{N}$ has a stronger mobility than $\mathrm{P}$, mainly because nitrate nitrogen mobility is very strong. Under the condition of good ventilation, ammonia nitrogen can be converted into nitrate nitrogen through the action of nitrifying bacteria. The nitrate nitrogen which has a good mobility can easily spread to the root surface, realizing the rapid absorption of $\mathrm{N}$ elements and promoting the changes of root morphology and the biomass increase (Wang, 2004). 


\section{Scientific fertilization of artificial forests in new reclamation areas}

$\mathrm{N}$ and $\mathrm{P}$ are the most demanding limiting nutrients for plant root growth. According to the cost-benefit theory, root growth depends on a large amount of nitrogen and phosphorus input (Eissenstat and Yanai, 1997; Nadelhoffer, 2000; Norby and Jackson, 2000). For example, Jackson et al. (1997) found that for every unit of nitrogen absorbed by the root system, 41 units of carbon were consumed (Jackson et al., 1997). Statistics also showed that when the first fruit of tomato grew to $4 \mathrm{~cm}$ in length, the amount of phosphorus absorbed from soil accounted for about $90 \%$ of that in the whole growth period. Therefore, the effectiveness of soil $\mathrm{N}$ and $\mathrm{P}$ significantly affected root growth. Hendrick and Pregitzer (1996) believed that root biomass may be positively correlated with soil nutrient availability or negatively correlated, depending on the plant species and the spatial heterogeneity of available nutrients distributed in soil (Hendrick and Pregitzer, 1996). In this study, it was found that the total length, surface area, volume, biomass, root length density and surface area density of the roots significantly increased when $1 \mathrm{~g}, 3 \mathrm{~g}$ $\mathrm{N}$ and $\mathrm{P}$ were applied, among which the effect of $3 \mathrm{~g} \mathrm{~N}$ and $\mathrm{P}$ was the best, showing that $\mathrm{N}$ and $\mathrm{P}$ promoted (positive feedback) the root system. When 5-20 g N and $\mathrm{P}$ were applied, the total length, surface area, volume, biomass, root length density and surface area density of the root significantly reduced, reflecting the inhibition (negative feedback) of $\mathrm{N}$ and $\mathrm{P}$ on the root system. Among those, no root growth was found in the soil core when $11 \mathrm{~g} \mathrm{~N}$ was applied, seriously hindering the growth of the root system. Although the soil's $\mathrm{N}$ and $\mathrm{P}$ content in coastal salt land is very low for the growth of vegetation, it is not better to apply more $\mathrm{N}$ and $\mathrm{P}$ but better to master the threshold of $\mathrm{N}$ and $\mathrm{P}$ required by plants. In this way a scientific and reasonable fertilization can be achieved.

Plant root growth, death and turnover is a dynamic process. The time of experiment design makes a great difference to the results of the experiment. In different months, root growth, death and turnover laws are constantly changing (Pregitzer et al., 1993). The effect of fertilization on the annual and monthly dynamics of root system needs to be further studied in the future. In this experiment, root systems were not classified. In different $\mathrm{N}$ and $\mathrm{P}$ treatment cases, the differences between all levels of $\mathrm{N}$ and $\mathrm{P}$ content within the root sequences and the different treatments are not clear. From the research of root physiological processes of carbon - nitrogen - phosphorus, it's more helpful for knowing the root better, and more helpful for knowing soil's $\mathrm{N}$ and $\mathrm{P}$ availability and reaction mechanism of spatial heterogeneity better, all of which needs to be discussed further.

\section{Conclusions}

The results showed that reasonable addition of $\mathrm{N}$ and $\mathrm{P}$ could significantly change the morphology and biomass of root system. Reasonable $\mathrm{N}$ and $\mathrm{P}$ add $(3 \mathrm{~g})$ can make the root total length, surface area, volume, biomass, root length density and root surface area density increase significantly, reflecting the promotion of root system (positive feedback) of $\mathrm{N}$ and $\mathrm{P}$. More of that than the threshold will reduce these indexes gradually, reflecting the nitrogen and phosphorus's inhibition to the root system (negative feedback). With the treatments of different $\mathrm{N}$ and $\mathrm{P}$ gradients, the root diameter showed a tendency of first thinning and then coarsening, and the specific root length and specific surface area showed a trend of first increasing and then decreasing. The main reason for the occurrence was that the mobility of the two elements in soil was related to the absorption strategy of the root system. The study showed that the application of $3 \mathrm{~g} \mathrm{~N}$ and $\mathrm{P}$ into the soil filled 
with $196.25 \mathrm{~cm}^{3}$ significantly promoted the growth of the root system, and more of that than the threshold will lead in the inhibition of $\mathrm{N}$ and $\mathrm{P}$ on the root. Short-term $\mathrm{N}$ and $\mathrm{P}$ addition had significant effects on total length, diameter, surface area, volume, biomass, root length density, specific root length, specific surface area and root surface area density of the privet root system $(P<0.05)$.

Acknowledgments. This project was supported by Science and Technology Commission of Shanghai Municipality (17DZ1202801). The soil research institute, planning research institute and ecological research institute of Shanghai Academy of Landscape Architecture Science and Planning also gave strong support to the research.

\section{REFERENCES}

[1] Bardgett, R. D., Mommer, L., DeVries, F. T. (2014): Going underground: root traits as drivers of ecosystem processes. - Trends in Ecology \& Evolution 29(12): 692-699.

[2] Bates, T. R., Lynch, J. P. (1996): Stimulation of root hair elongation in Arabidopsis thaliana by low phosphorus availability. - Plant Cell and Environment 19: 529-538.

[3] Burton, A. J., Pregitzer, K. S., Hendrick, R. L. (2000): Relationships between fine root dynamics and nitrogen availability in Michigan northern hardwood forests. - Oecologia 125(3): 389-399.

[4] Cotrufo, M. F., Gorissen, A. (1997): Elevated $\mathrm{CO}_{2}$ enhances below-ground $\mathrm{C}$ allocation in three perennial grass species at different levels of N availability. - New Phytologist 137(3): 421-431.

[5] Cuevas, E., Brown, S., Lugo, A. E. (1991): Above- and belowground organic matter storage and production in a tropical pine plantation and a paired broadleaf secondary forest. - Plant Soil 135(2): 257-268.

[6] Eissenstat, D. (1992): Costs and benefits of constructing roots of small diameter1. - Journal of Plant Nutrition 15(6-7): 763-782.

[7] Eissenstat, D. M., Yanai, R. D. (1997): The Ecology of Root Lifespan. - Advances in Ecological Research 27: 1-60.

[8] Eissenstat, D. M., Wells, C. E., Yanai, R. D., Whitbeck, J. L. (2000): Building roots in a changing environment: implications for root longevity. - New Phytologist 147(1): 33-42.

[9] Fitter, A. H., Stickland, T. R. (1991): Architectural Analysis of Plant Root Systems. 2. Influence of Nutrient Supply on Architecture in Contrasting Plant Species. - New Phytologist 118(3): 383-389.

[10] Fitter, A. H., Stickland, T. R., Harvey, M. L., Wilson, G. W. (2010): Architectural analysis of plant root systems. Architectural correlates of exploitation efficiency. - New Phytologist 121(2): 243-248.

[11] Gordon, W. S., Jackson, R. B. (2000): Nutrient Concentrationsin Fine Roots. - Ecology 81(1): 275-280.

[12] Guo, D. L., Mitchell, R. J., Hendricks, J. J. (2004): Fine root branch orders respond differentially to carbon source-sink manipulations in a longleaf pine forest. - Oecologia 140(3): 450-457.

[13] Hendrick, R. L., Pregitzer, K. S. (1996): Applications of minirhizotrons to understand root function in forests and other natural ecosystems. - Plant Soil 185(2): 293-304.

[14] Jackson, R. B., Mooney, H. A., Schulze, E. D. (1997): A global budget for fine root biomass, surface area, and nutrient contents. - Proc Natl Acad Sci USA 94(14): 7362-7366.

[15] Jiang, H. (2016): Space and temporal distribution of fine root and its influencing factors research in plantation of coastal salt land. - East China Normal University. (in Chinese).

[16] Kern, C. C., Friend, A. L., Johnson, J. M. F., Coleman, M. D. (2004): Fine root dynamics in a developing Populus deltoides plantation. - New Phytologist 24(6): 651. 
[17] King, J. S., Thomas, R. B., Strain, B. R. (1997): Morphology and tissue quality of seedling root systems of Pinus taeda and Pinus ponderosa as affected by varying $\mathrm{CO}_{2}$, temperature, and nitrogen. - Plant Soil 195(1): 107-119.

[18] Kou, L., Guo, D., Yang, H., Gao, W., Li, S. (2015): Growth, morphological traits and mycorrhizal colonization of fine roots respond differently to nitrogen addition in a slash pine plantation in subtropical China. - Plant Soil 391(1-2): 207-218.

[19] Lynch, J. (1995): Root Architecture and Plant Productivity. - Plant Physiology 109(1): 713.

[20] Majdi, H. (2001): Changes in fine root production and longevity in relation to water and nutrient availability in a Norway spruce stand in northern Sweden. - Tree Physiology 21(14): 1057.

[21] Mcgrath, D. A., Duryea, M. L., Cropper, W. P. (2001): Soil phosphorus availability and fine root proliferation in Amazonian agroforests 6 years following forest conversion. Agriculture Ecosystems \& Environment 83(3): 271-284.

[22] Messier, C. (2002): Does soil heterogeneity and compaction in ingrowth-cores affect growth and morphology of black spruce fine-roots? - Commun Soil Sci Plant 33(7-8): 1027-1037.

[23] Nadelhoffer, K. J. (2000): The potential effects of nitrogen deposition on fine-root production inforest ecosystems. - New Phytologist 147(1): 131-139.

[24] Norby, R. J., Jackson, R. B. (2000): Research Review: Root Dynamics and Global Change: Seeking an Ecosystem Perspective. - New Phytologist 147(1): 3-12.

[25] Peterjohn, W. T., Foster, C. J., Christ, M. J., Adams, M. B. (1999): Patterns of nitrogen availability within a forested watershed exhibiting symptoms of nitrogen saturation. Forest Ecology and Management 119(1-3): 247-257.

[26] Pregitzer, K. S., Hendrick, R. L., Fogel, R. (1993): The Demography of Fine Roots in Response to Patches of Water and Nitrogen. - New Phytologist 125(3): 575-580.

[27] Pregitzer, K. S., Kubiske, M. E., Yu, C. K., Hendrick, R. L. (1997): Relationships among root branch order, carbon, and nitrogen in four temperate species. - Oecologia 111(3): 302308.

[28] Pregitzer, K. S., Deforest, J. L., Burton, A. J., Allen, M. F., Ruess, R. W., Hendrick, R. L. (2002): Fine Root Architecture of Nine North American Trees. - Ecological Monographs 72(2): 293-309.

[29] Robinson, D. (2010): The responses of plants to non-uniform supplies of nutrients. - New Phytologist 127(4): 635-674.

[30] Schiefelbein, J. W., Benfey, P. N. (1991): The development of plant roots: new approaches to underground problems. - Plant Cell 3(11): 1147.

[31] Schmid, I., Kazda, M. (2002): Root distribution of Norway spruce in monospecific and mixed stands on different soils. - Forest Ecology and Management 159(1): 37-47.

[32] Son, Y., Wang, J. H. (2010): Fine root biomass, production and turnover in a fertilized Larix leptolepis plantation in central Korea. - Ecology Research 18(3): 339-346.

[33] Wang, Q. C. (2004): Fine roots responses of manchurian ash and korean larch to soil nutrients heterogeneity. - Northeast Forestry University. (in Chinese).

[34] Wang, X. R., Wang, Z. Q., Han, Y. Z., Gu, J. C., Guo, D. L., Mei, L. (2005): Variations of fine root diameter with root order in manchurian ash and dahurian larch plantations. - Acta Phytotaxonomica Sinica 26: 871-877. (in Chinese).

[35] Wells, C. E., Glenn, D. M., Eissenstat, D. M. (2002): Changes in the risk of fine-root mortality with age: a case study in peach, Prunus persica (Rosaceae). - American Journal of Botany 89(1): 79-87.

[36] Wells, C. E., Glenn, D. M., Eissenstat, D. M. (2010): Soil insects alter fine root demography in peach (Prunus persica). - Plant Cell Environment 25(3): 431-439.

[37] Wurzburger, N., Wright, S. J. (2016): Fine root responses to fertilization reveal multiple nutrient limitation in a lowland tropical forest. - Ecology 96(8): 2137-2146. 
[38] Yang, Y., Chen, G., Lin, P., Huang, R., Chen, Y., He, Z. (2003): Fine root distribution, seasonal pattern and production in a native forest and monoculture plantations in subtropical China. - Acta Ecologica Sinica 23(9): 1719-1730. (in Chinese). 